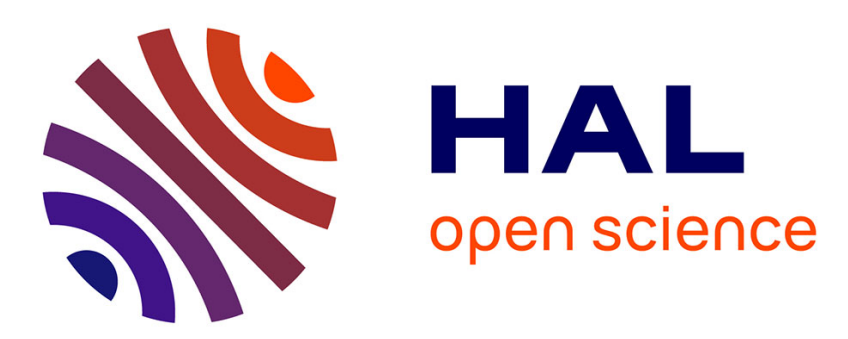

\title{
A High Performance Sensorless Indirect Stator Flux Orientation Control of Induction Motor Drive
}

\author{
Mohamed Boussak, Kamel Jarray
}

\section{To cite this version:}

Mohamed Boussak, Kamel Jarray. A High Performance Sensorless Indirect Stator Flux Orientation Control of Induction Motor Drive. IEEE Industrial Electronics, 2006, Vol. 53 ( $\mathrm{n}^{\circ} 1$ ), pp. 41-49. 10.1109/TIE.2005.862319 . hal-00334252

\section{HAL Id: hal-00334252 \\ https://hal.science/hal-00334252}

Submitted on 24 Oct 2008

HAL is a multi-disciplinary open access archive for the deposit and dissemination of scientific research documents, whether they are published or not. The documents may come from teaching and research institutions in France or abroad, or from public or private research centers.
L'archive ouverte pluridisciplinaire HAL, est destinée au dépôt et à la diffusion de documents scientifiques de niveau recherche, publiés ou non, émanant des établissements d'enseignement et de recherche français ou étrangers, des laboratoires publics ou privés. 


\title{
A High-Performance Sensorless Indirect Stator Flux Orientation Control of Induction Motor Drive
}

\author{
Mohamed Boussak, Member, IEEE, and Kamel Jarray
}

\begin{abstract}
A new method for the implementation of a sensorless indirect stator-flux-oriented control (ISFOC) of induction motor drives with stator resistance tuning is proposed in this paper. The proposed method for the estimation of speed and stator resistance is based only on measurement of stator currents. The error of the measured $q$-axis current from its reference value feeds the proportional plus integral (PI) controller, the output of which is the estimated slip frequency. It is subtracted from the synchronous angular frequency, which is obtained from the output integral plus proportional (IP) rotor speed controller, to have the estimated rotor speed. For current regulation, this paper proposes a conventional PI controller with feedforward compensation terms in the synchronous frame. Owing to its advantages, an IP controller is used for rotor speed regulation. Stator resistance updating is based on the measured and reference $d$-axis stator current of an induction motor on $d-q$ frame synchronously rotating with the stator flux vector. Experimental results for a 3-kW induction motor are presented and analyzed by using a dSpace system with DS1102 controller board based on the digital signal processor (DSP) TMS320C31. Digital simulation and experimental results are presented to show the improvement in performance of the proposed method.
\end{abstract}

Index Terms-Feedforward decoupling, induction motor, sensorless vector control, stator-flux-oriented control, stator resistance estimation.

\section{NOMENCLATURE}

$\begin{array}{ll}v_{d s}, v_{q s} & d, q \text {-axis stator voltage components. } \\ i_{d s}, i_{q s} & d, q \text {-axis stator current components. } \\ \Phi_{d s}, \Phi_{q s} & d, q \text {-axis stator flux components. } \\ R_{s}, R_{r} & \text { Stator and rotor winding resistance. } \\ L_{s}, L_{r} & \text { Stator and rotor self-inductance. } \\ M & \text { Mutual inductance. } \\ N_{p} & \text { Number of pole pairs. } \\ p \triangleq d / d t & \text { Differential operator. } \\ \omega_{s}, \omega_{r} & \text { Synchronous and rotor angular speed. } \\ \omega_{s l} & \text { Slip angular speed }\left(\omega_{s}-\omega_{r}\right) . \\ T_{e}, T_{l} & \text { Electromagnetic and load torque. } \\ J & \text { Moment of inertia. }\end{array}$

Manuscript received April 6, 2004; revised October 12, 2004. Abstract published on the Internet November 25, 2005.

M. Boussak is with the Laboratoire de Génie des Systèmes Electriques (LGSE), Equipe Systèmes Mécatroniques (ESM), Ecole Généraliste d'Ingénieurs de Marseille (EGIM), Technopôle de Château Gombert, Marseille Cedex 13 13383, France (e-mail: mohamed.boussak@egim-mrs.fr).

K. Jarray is with the Département de Génie Electrique, Ecole Nationale d'Ingénieurs de Gabès (ENIG), Gabès 6029, Tunisia (e-mail: Kamel.Jarray@ esstt.rnu.tn).

Digital Object Identifier 10.1109/TIE.2005.862319

$\begin{array}{ll}f & \text { Friction constant. } \\ \tau_{s}, \tau_{r} & \begin{array}{l}\text { Stator and rotor time constant. } \\ \text { Proportional gain of the integral plus proportional } \\ K_{p}\end{array} \\ K_{i} & \begin{array}{l}\text { (IP) speed controller. } \\ \text { Integral gain of the IP speed controller. } \\ K_{i p}\end{array} \\ \begin{array}{l}\text { Proportional gain of the proportional plus integral } \\ \text { (PI) current controller. }\end{array} \\ K_{i i} \quad \begin{array}{l}\text { Integral gain of the PI current controller. } \\ K_{\omega p}\end{array} \\ \begin{array}{l}\text { Proportional gain of the PI slip speed estimation } \\ \text { controller. }\end{array} \\ K_{\omega i} \quad \begin{array}{l}\text { Integral gain of the PI slip speed estimation } \\ \text { controller. }\end{array} \\ \begin{array}{l}\text { Integral gain of the estimated stator resistance } \\ \text { variation controller. }\end{array} \\ \text { Total leakage constant. } \\ \text { Estimated and reference value. }\end{array}$

\section{INTRODUCTION}

$\mathbf{V}$ ECTOR control has been widely used for the highperformance drive of the induction motor. As in dc motor, torque control of the induction motor is achieved by controlling torque and flux components independently. Vector control techniques can be separated into two categories: direct and indirect flux vector orientation control schemes. For direct control methods, the flux vector is obtained by using stator terminal quantities, while indirect methods use the machine slip frequency to achieve field orientation.

The overall performance of field-oriented-controlled induction motor drive systems is directly related to the performance of current control. Therefore, decoupling the control scheme is required by compensation of the coupling effect between $q$-axis and $d$-axis current dynamics [1]-[3].

All high-performance vector-controlled induction motor drives require accurate rotational speed or rotational position information for feedback control. This information is provided by an incremental encoder, which is the most common positioning transducer used today in industrial applications. The use of this sensor implies more electronics, higher cost, lower reliability, difficulty in mounting in some cases such as motor drives in harsh environment and high speed drives, increase in weight, increase in size, and increase electrical susceptibility.

To overcome these problems, in recent years, the elimination of those transducers has been considered as an attractive prospect. Numerous approaches have been proposed to estimate rotor velocity and/or position from machine terminal properties, such as stator current or voltage. 
In the existing literature, many approaches have been suggested for speed sensorless vector control induction motor drives. These methods are based on the following schemes:

- harmonic caused by machine saliency [4], [5];

- Model Reference Adaptive System (MRAS) [6], [7];

- extended Kalman filter (EKF) [8], [9];

- artificial neural network (ANN) [10], [11];

- extended Luenberger observers [12], [13];

- instantaneous reactive power [14], [15].

Some of these methods require specially modified machines and the injection of disturbance signals or the use of a machine model. Otherwise, all other methods for speed estimation using a machine model fed by stator quantities are parameter dependent; therefore, parameter errors can degrade speed control performance. Thus, some kind of parameter adaptation is required in order to obtain high-performance sensorless vector control drive.

At very low speed, indirect stator-flux-oriented control (ISFOC) of induction motor drive is particularly sensitive to an accurate stator resistance value in the stator flux. To overcome this problem, online tuning stator resistance variation of the induction motor is essential in order to maintain the dynamic performance of a sensorless ISFOC drive. Recently, many works dealing with drives without shaft transducers have been developed using different approaches to estimate rotor speed and stator resistance [16]-[22]. Most of these approaches require additional sensors that were not strictly used in standard ISFOC drive, thus increasing cost and complexity that may rule out practical use.

In this paper, we propose a novel method of sensorless ISFOC induction motor drive with stator resistance tuning and dynamic feedforward decoupling scheme able to operate down to zero speed, which require only current and dc bus voltage sensors. The dynamic feedforward decoupling scheme is based on the conventional PI controller with compensation terms in the synchronous frame. The estimated speed is obtained starting from the measurement of stator currents and those of references generated by the control algorithm. To ensure the dynamic performance of the induction motor drive, this new structure must be robust with respect to stator resistance variation. Online estimation of stator resistance variation is obtained by means of the error between $d$-axis stator current and that generated by the algorithm command. By using a pure integral controller, we can estimate stator resistance variation. The new method for sensorless ISFOC of induction motor drive is implemented with stator resistance tuning at rated, low, and zero speed operations.

The performance of the drive was found to be excellent in both simulation and experiment.

\section{StATOR-FluX-ORIEnTATION MOdEL}

For ISFOC, the stator flux vector is aligned with $d$-axis and setting the stator flux to be constant equal to the rated flux, which means $\Phi_{d s}=\Phi_{s}$ and $\Phi_{q s}=0$.

The dynamic model of an induction motor can be represented according to the usual $d$-axis and $q$-axis components in a synchronous rotating frame as

$$
\begin{aligned}
v_{d s}= & \frac{R_{s}\left(\tau_{s}+\tau_{r}\right)}{\tau_{r}}\left(1+\frac{\sigma \tau_{s} \tau_{r}}{\tau_{s}+\tau_{r}} p\right) i_{d s} \\
& -\sigma L_{s} \omega_{s l} i_{q s}-\frac{\Phi_{s}}{\tau_{r}} \\
v_{q s}= & \frac{R_{s}\left(\tau_{s}+\tau_{r}\right)}{\tau_{r}}\left(1+\frac{\sigma \tau_{s} \tau_{r}}{\tau_{s}+\tau_{r}} p\right) i_{q s} \\
& +\sigma L_{s} \omega_{s l} i_{d s}+\omega_{r} \Phi_{s} \\
\Phi_{s}= & L_{s} \frac{1+\sigma \tau_{r} p}{1+\tau_{r} p} i_{d s}-\frac{\sigma \tau_{r} L_{s} \omega_{s l}}{1+\tau_{r} p} i_{q s} \\
\omega_{s l}= & \frac{L_{s}}{\tau_{r}} \frac{1+\sigma \tau_{r} p}{\Phi_{s}-\sigma L_{s} i_{d s}} i_{q s} \\
T_{e}= & N_{p} \Phi_{s} i_{q s}
\end{aligned}
$$

where $\sigma=1-\left(M^{2} / L_{s} L_{r}\right), \tau_{s}=L_{s} / R_{s}$, and $\tau_{r}=L_{r} / R_{r}$.

It can be seen that if the stator flux is kept constant, the torque can be controlled by controlling the $q$-axis current.

The electromagnetic torque equation and the electrical angular speed motor are related by

$$
J \frac{d \omega_{r}}{d t}+f \omega_{r}=N_{p}\left(T_{e}-T_{l}\right)
$$

\section{Feedforward Decoupling Controller}

It can be seen that the $d$-axis and $q$-axis voltage equations are coupled by the terms $-\sigma L_{s} \omega_{s l} i_{q s}-\left(\Phi_{s} / \tau_{r}\right)$ and $\sigma L_{s} \omega_{s l} i_{d s}+$ $\omega \Phi_{s}$. These terms are considered as disturbances and are cancelled by using a decoupling method that utilizes nonlinear feedback of the coupling voltages. If the decoupling method is implemented the voltage equations become

$$
\begin{aligned}
& v_{d}=v_{d s}+E_{d}=\frac{R_{s}\left(\tau_{s}+\tau_{r}\right)}{\tau_{r}}\left(1+\frac{\sigma \tau_{s} \tau_{r}}{\tau_{s}+\tau_{r}} p\right) i_{d s} \\
& v_{q}=v_{q s}+E_{q}=\frac{R_{s}\left(\tau_{s}+\tau_{r}\right)}{\tau_{r}}\left(1+\frac{\sigma \tau_{s} \tau_{r}}{\tau_{s}+\tau_{r}} p\right) i_{q s}
\end{aligned}
$$

where $E_{d}=\sigma L_{s} \omega_{s l} i_{q s}+\left(\Phi_{s} / \tau_{r}\right)$ and $E_{q}=-\sigma L_{s} \omega_{s l} i_{d s}-$ $\omega \Phi_{s} ; E_{d}$ and $E_{q}$ are, respectively, the $d$ - and $q$-back electromotive force (EMF).

Thus, the dynamics of the $d$-axis and $q$-axis currents are now represented by simple linear first-order differential equations. Therefore, it is possible to effectively control the currents with a PI controller.

In Fig. $1, K_{i p}$ and $K_{i i}$ denote proportional and integral gains of the PI $d, q$ axis current controller, respectively. $G_{d}(p), G_{q}(p)$ are the nondecoupling electrical $d, q$ axis transfer functions of the induction machine. It should be noted that the estimated values, denoted by ${ }^{\wedge}$, are introduced to cancel out the coupling terms in the induction motor model.

If we assume that the back EMFs are canceled by the feedforward compensation term, we obtain

$$
G_{d}(p)=G_{q}(p)=\frac{K_{c}}{1+\tau_{c} p}
$$




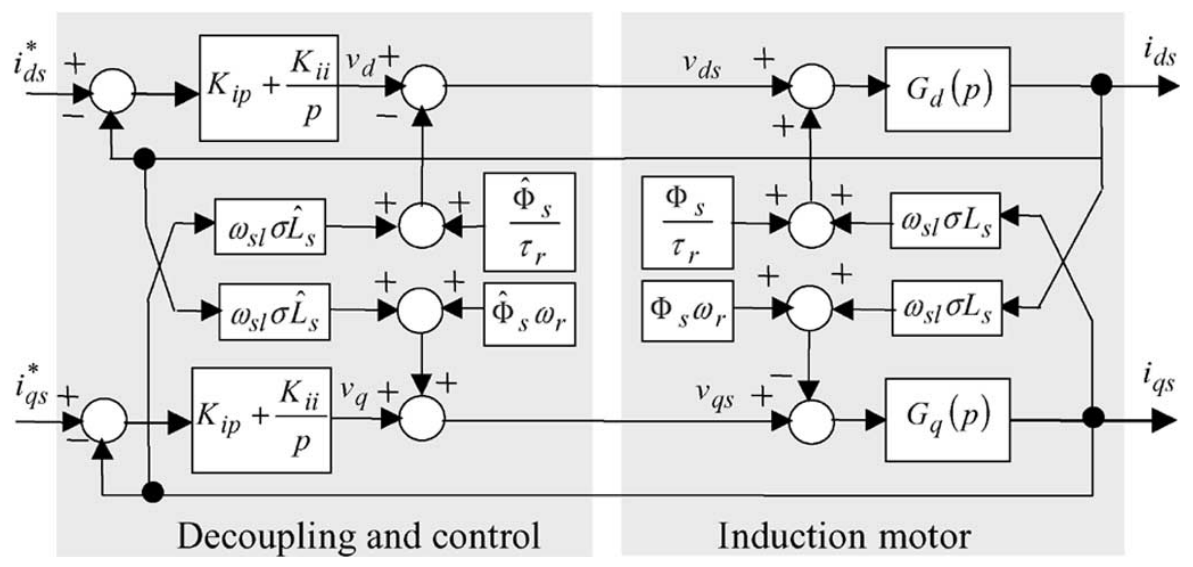

Fig. 1. Block diagram of the conventional PI controller with feedforward decoupling method.

where $K_{c}=\tau_{r} / R_{s}\left(\tau_{s}+\tau_{r}\right)$ is a gain and $\tau_{c}=\sigma \tau_{s} \tau_{r} /$ $\left(\tau_{s}+\tau_{r}\right)$ is a time constant.

The closed-loop current transfer function is

$$
\frac{i_{d s}(p)}{i_{d s}^{*}(p)}=\frac{\omega_{n i}^{2}\left(1+\frac{K_{i p}}{K_{i i}} p\right)}{p^{2}+2 \xi \omega_{n i} p+\omega_{n i}^{2}}
$$

where

$$
\omega_{n i}=\sqrt{\frac{K_{c} K_{i i}}{\tau_{c}}} \text { and } \xi=\frac{1+K_{c}+K_{i p}}{2 \omega_{n i} \tau_{c}} .
$$

$\omega_{n i}$ and $\xi$ denote natural frequency and damping ratio, respectively.

When the dynamics of the $d$ - and $q$-axes currents are equivalent, the PI gains can be copied to the $q$-axis controller.

\section{Sensorless Speed Control Algorithm}

\section{A. Slip Speed Estimation}

From (3) and (4), and by neglecting the term $\left(\tau_{r} \sigma \omega_{s l}\right)^{2}$, we obtain the following relation between slip speed $\omega_{s l}$ and $q$-axis stator current $i_{q s}$ :

$$
\omega_{s l} \approx \frac{L_{s}\left(1+\sigma \tau_{r} p\right)^{2}}{(1-\sigma) \tau_{r} \Phi_{s}} i_{q s}
$$

It can be seen that the slip speed is represented by secondorder differential equation $q$-axis current. Therefore, it is possible to estimate the slip speed using the regulation in closed-loop $q$-axis current. We propose a new slip speed estimation based on measurement of stator currents.

From (3) and (4), we obtain the following reference currents with stator flux reference and slip angular frequency estimation:

$$
\begin{aligned}
& p i_{d s}^{*}=-\frac{1}{\sigma \tau_{r}} i_{d s}^{*}+\frac{1+\tau_{r} p}{\sigma L_{s} \tau_{r}} \Phi_{s}^{*}+\hat{\omega}_{s l} i_{q s}^{*} \\
& p i_{q s}^{*}=-\frac{1}{\sigma \tau_{r}} i_{q s}^{*}+\frac{\Phi_{s}^{*}}{\sigma L_{s}} \hat{\omega}_{s l}-i_{d s}^{*} \hat{\omega}_{s l} .
\end{aligned}
$$

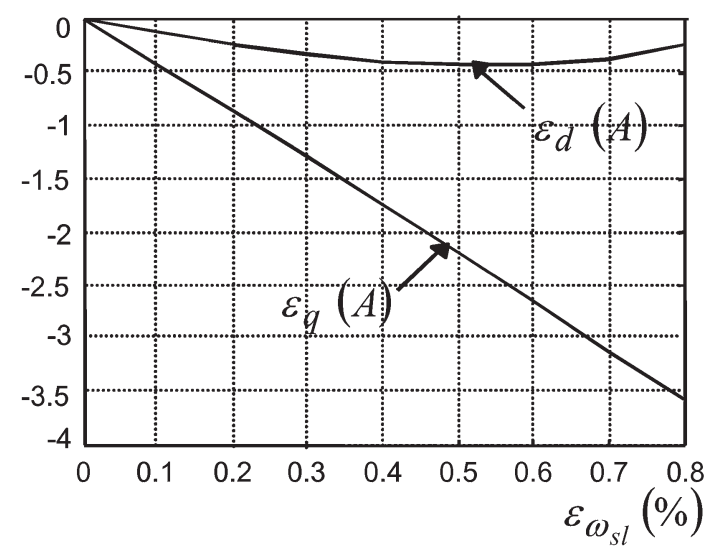

Fig. 2. $d$-axis and $q$-axis current error with slip speed error.

We define two error components between reference and measurement $d$-axis and $q$-axis currents through

$$
\begin{aligned}
& \varepsilon_{d}=i_{d s}^{*}-i_{d s} \\
& \varepsilon_{q}=i_{q s}^{*}-i_{q s} .
\end{aligned}
$$

The slip speed error is defined by

$$
\varepsilon_{\omega_{s l}}=\omega_{s l}-\hat{\omega}_{s l}
$$

We express the measured and reference variables according to these errors, then we replace them in (12) and (13) and we obtain

$$
p\left[\begin{array}{l}
\varepsilon_{d} \\
\varepsilon_{q}
\end{array}\right]=\left[\begin{array}{cc}
-\frac{1}{\sigma \tau_{r}} & \omega_{s l} \\
-\omega_{s l} & -\frac{1}{\sigma \tau_{r}}
\end{array}\right]\left[\begin{array}{l}
\varepsilon_{d} \\
\varepsilon_{q}
\end{array}\right]+\left[\begin{array}{c}
-i_{q s} \\
i_{d s}-\frac{\Phi_{s}^{*}}{\sigma L_{s}}
\end{array}\right] \varepsilon_{\omega_{s l}} .
$$

We graphically studied the variation of stator current error according to slip speed error. Fig. 2 shows that the $q$-axis current error varies almost linearly with the variation of the slip speed error and that the $d$-axis current error is weak and negligible in relation to $\varepsilon_{q}[23]-[25]$.

This result is justified by (11). Thus, it is possible to use only the $q$-axis error $\varepsilon_{q}$ for the estimation of slip speed by using the second row of (17), which is reduced to

$$
\left(1+\sigma \tau_{r} p\right) \varepsilon_{q}=\sigma \tau_{r}\left(i_{d s}-\frac{\Phi_{s}^{*}}{\sigma L_{s}}\right) \varepsilon_{\omega_{s l}} .
$$




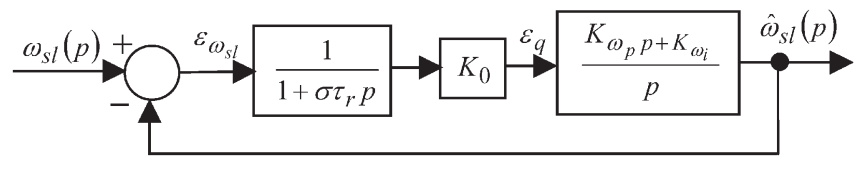

Fig. 3. Block diagram of slip speed estimation.

The simulation results studied in [24] and [25] show that the $d$-axis stator current does not vary in a significant manner according to slip speed, which enables us to assume that $d$-axis stator current is equal to the steady state current $i_{d s 0}$.

From (18), we establish the transfer function connecting the slip speed error to the $q$-axis current, i.e.,

$$
\frac{\varepsilon_{q}(p)}{\varepsilon_{\omega_{s l}}(p)}=\frac{K_{0}}{\sigma \tau_{r} p+1}
$$

where

$$
K_{0}=\sigma \tau_{r}\left(i_{d s}-\frac{\Phi_{s}^{*}}{\sigma L_{s}}\right)
$$

To estimate slip speed, we used a PI controller. The sign of the gain $K_{0}$ is negative; thus, to obtain positive gains of the regulator, the inversion of sign will be carried out on the comparative of the $q$-axis current.

From (16), it should be noted that the dynamic slip speed error is now represented by the simple linear first-order differential equation with $q$-axis current error. Therefore, it is possible to effectively control slip speed error with a PI controller.

Thus, we obtain the estimated slip speed

$$
\hat{\omega}_{s l}=\frac{K_{\omega p} p+K_{\omega i}}{p}\left(i_{q s}-i_{q s}^{*}\right)
$$

We obtain the block diagram in Fig. 3.

From Fig. 3, the closed-loop transfer function can be expressed with

$$
\frac{\hat{\omega}_{s l}(p)}{\omega_{s l}^{*}(p)}=\frac{\omega_{n}^{2}\left(1+\frac{K_{\omega p}}{K_{\omega i}} p\right)}{p^{2}+2 \xi \omega_{n} p+\omega_{n}^{2}}
$$

where

$$
\omega_{n}=\sqrt{\frac{K_{0} K_{\omega i}}{\sigma \tau_{r}}} \text { and } \xi=\frac{K_{0} K_{\omega p}+1}{2 \omega_{n} \sigma \tau_{r}} .
$$

$\omega_{n}$ and $\xi$ denote natural frequency and damping ratio, respectively.

By setting the damping ratio $\xi=1$, the characteristic equation of the closed-loop system admits a double pole. For a given damping ratio, the second-order systems give a constant value for $\omega_{n} t_{r}=k$. For example, if we have a damping ratio $\xi=1$, we obtain $\omega_{n} t_{r} \approx 4.75$.

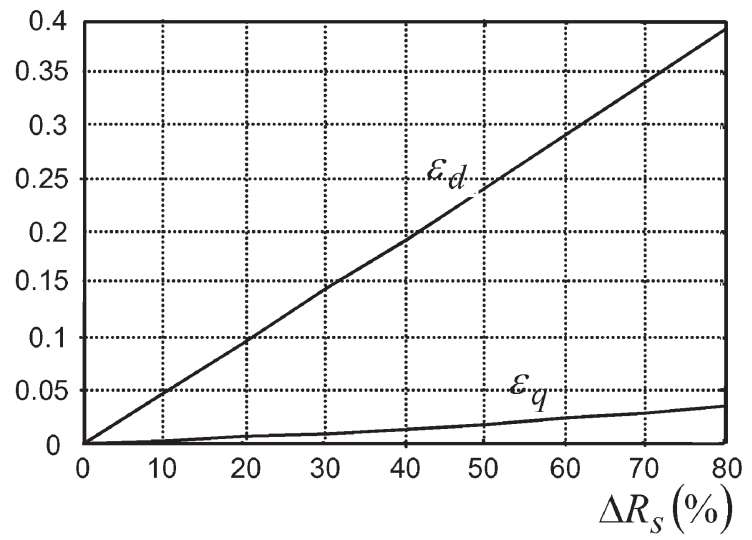

Fig. 4. $d$-axis and $q$-axis current error with stator resistance variation.

The proportional and integral gains of the PI controller are given as

$$
\begin{aligned}
K_{\omega p} & =\frac{2 \sigma \tau_{r} \xi\left(\frac{k}{t_{r}}\right)-1}{K_{0}} \\
K_{\omega i} & =\frac{\sigma \tau_{r}\left(\frac{k}{t_{r}}\right)^{2}}{K_{0}}
\end{aligned}
$$

where $t_{r}$ is the response time that is defined as the time required for the step response to rise from $0 \%$ to $95 \%$ of its final value.

\section{B. Variation Stator Resistance Estimation}

So as to choose correctly the variable that allows us to identify stator resistance variation, we graphically studied the variation of the $d$-axis and $q$-axis current error according to the stator resistance variation [24], [25].

Fig. 4 shows that the $d$-axis current error strongly varies almost linearly with stator resistance variation $\Delta R_{s}$. The $q$-axis current error remains weak and can be neglected in relation to the $d$-axis current error. Thus, we use only $d$-axis current error for the estimation of stator resistance variation.

The $d$-axis reference stator voltage is given by

$$
v_{d s}^{*}=R_{s 0} i_{d s}^{*}+\frac{d \Phi_{d s}^{*}}{d t}
$$

where $R_{s 0}$ is the initial stator resistance.

Stator resistance variation generates a $d$-axis current and $q$-axis flux variations that are considered null for the control level. Thus, for stator resistance variation, the reference $d$-axis voltage fixed by $d$-axis flux and the $d$-axis reference current will be expressed according to stator flux and real current by

$$
v_{d s}^{*}=\left(R_{s 0}+\Delta R_{s}\right) i_{d s}+\frac{d \Phi_{d s}}{d t}-\omega_{s} \Phi_{q s} .
$$

Then, if we establish the equality between the two expressions (25) and (26), we obtain

$$
\varepsilon_{d}=\frac{i_{d s}}{R_{s 0}} \Delta R_{s}-\frac{1}{R_{s 0}} \frac{d \varepsilon_{\Phi_{d s}}}{d t}-\frac{1}{R_{s 0}} \omega_{s} \varepsilon_{\Phi_{q s}} .
$$




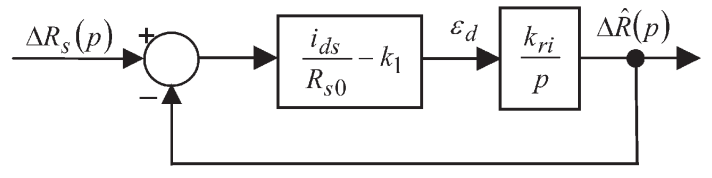

Fig. 5. Block diagram estimation of stator resistance variation.

In steady state, (27) can be put in the form

$$
\varepsilon_{d}=\varepsilon_{d 1}-\varepsilon_{d 2}
$$

where

$$
\begin{aligned}
& \varepsilon_{d 1}=\frac{i_{d s}}{R_{s 0}} \Delta R_{s} \\
& \varepsilon_{d 2}=\frac{1}{R_{s 0}} \omega_{s} \varepsilon_{\Phi_{q s}} .
\end{aligned}
$$

The simulation results studied in [24] and [25] show that the two terms $\varepsilon_{d 1}$ and $\varepsilon_{d 2}$ vary linearly with stator resistance variation $\Delta R_{s}$. So a first approximation can be used as

$$
\varepsilon_{d 2}=k_{1} \Delta R_{s}
$$

For a small stator resistance variation, the $d$-axis current can be regarded as constant. Thus, we can establish the transfer function connecting the stator resistance variation $\Delta R_{s}$ to the $d$-axis current error by

$$
\frac{\varepsilon_{d}(p)}{\Delta R_{s}(p)}=\frac{i_{d s}}{R_{s 0}}-k_{1}
$$

where

$$
k_{1} \leq \frac{i_{d s}}{R_{s 0}}
$$

In steady state, to cancel stator resistance variation error estimation, we chose an integral regulator type so that

$$
\Delta \hat{R}_{s}=\frac{k_{r i}}{p}\left(i_{d s}-i_{d s}^{*}\right)
$$

where $k_{r i}$ is the integral controller gain of the stator resistance variation estimation.

This enables us to obtain a first-order transfer function in closed loop. Block diagram estimation of stator resistance variation $\Delta R_{s}$ is presented in Fig. 5.

This method allows us to tune stator resistance by comparison of the $d$-axis reference stator current generated by the control with real $d$-axis current of the induction motor.

The integral of the difference will be injected into the control algorithm to compensate the stator resistance variation $\Delta R_{s}$. Fig. 6 shows the block diagram of the proposed sensorless SFOC of induction motor drive system with stator resistance tuning.

\section{Simulation And Experimental Results}

We have tested the robust controller at nominal and zero speed command with load torque applied for sensorless speed controlled induction motor drive with stator resistance tuning.

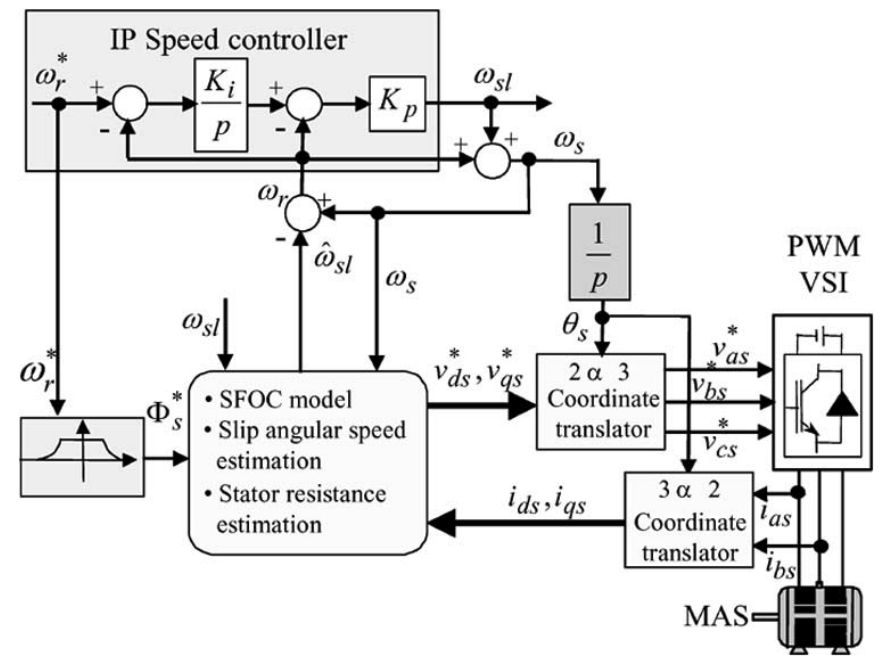

Fig. 6. Block diagram of sensorless stator-flux-oriented induction motor drive system.

Fig. 7 shows the experimental setup drive system of the hardware configuration.

The experimentation has been achieved with the help of Matlab-Simulink and dSpace system with DS1102 controller board based on the digital signal processor (DSP) TMS320C31. The voltage-source inverter (VSI) utilizes a diode rectifier front-end with dc bus voltage. The power circuit part is composed of intelligent power modules (IPMs) with rated $75 \mathrm{~A}$, $1200 \mathrm{~V}$ to drive a $3-\mathrm{kW}$ induction motor.

IPMs are constructed with insulated gate bipolar transistors (IGBTs) working at a switching frequency of $14 \mathrm{kHz}$ with a dead time of $3 \mu \mathrm{s}$. The pulsewidth-modulation (PWM) signals to control the power modules are generated by dSpace system. The sampling period of $500 \mu \mathrm{s}$ is selected since the actual computation time of the algorithm is about $300 \mu \mathrm{s}$. We measure two stator currents and dc bus voltage that are detected through Hall-type sensors. An incremental encoder position sensor delivering 1024 pulses per revolution is mounted on the rotor shaft only for comparison of the estimated and real speed of the induction motor. Load torque is produced by a dynamometer.

The IP speed controller is designed to stabilize the speedcontrol loop. The gains of the IP controller, $K_{p}$ and $K_{i}$, are determined using a design method to obtain a damping ratio of 1 . The induction motor parameters and different controller gain values are given in Tables I and II, respectively.

In Fig. 8(a) and (b), simulation and experimental results of the estimated and actual rotor speed, and in Fig. 8(c) and (d), simulation and estimated results of $d$-axis and $q$-axis stator flux, are presented a load torque variation. The estimated $d, q$ components of stator flux are obtained from the stator voltage model of induction motor in $d, q$ reference frame.

In addition, simulation results and measured stator phase currents are given in Fig. 8(e) and (f). Fig. 8(g) and (h) shows, respectively, simulation results and measurement of load torque and $q$-axis stator current. All of these sensorless speed control results are obtained with a motor startup from 0 to $1000 \mathrm{r} / \mathrm{min}$ and load torque applied and removed at $t=2$ and $4 \mathrm{~s}$, respectively. 


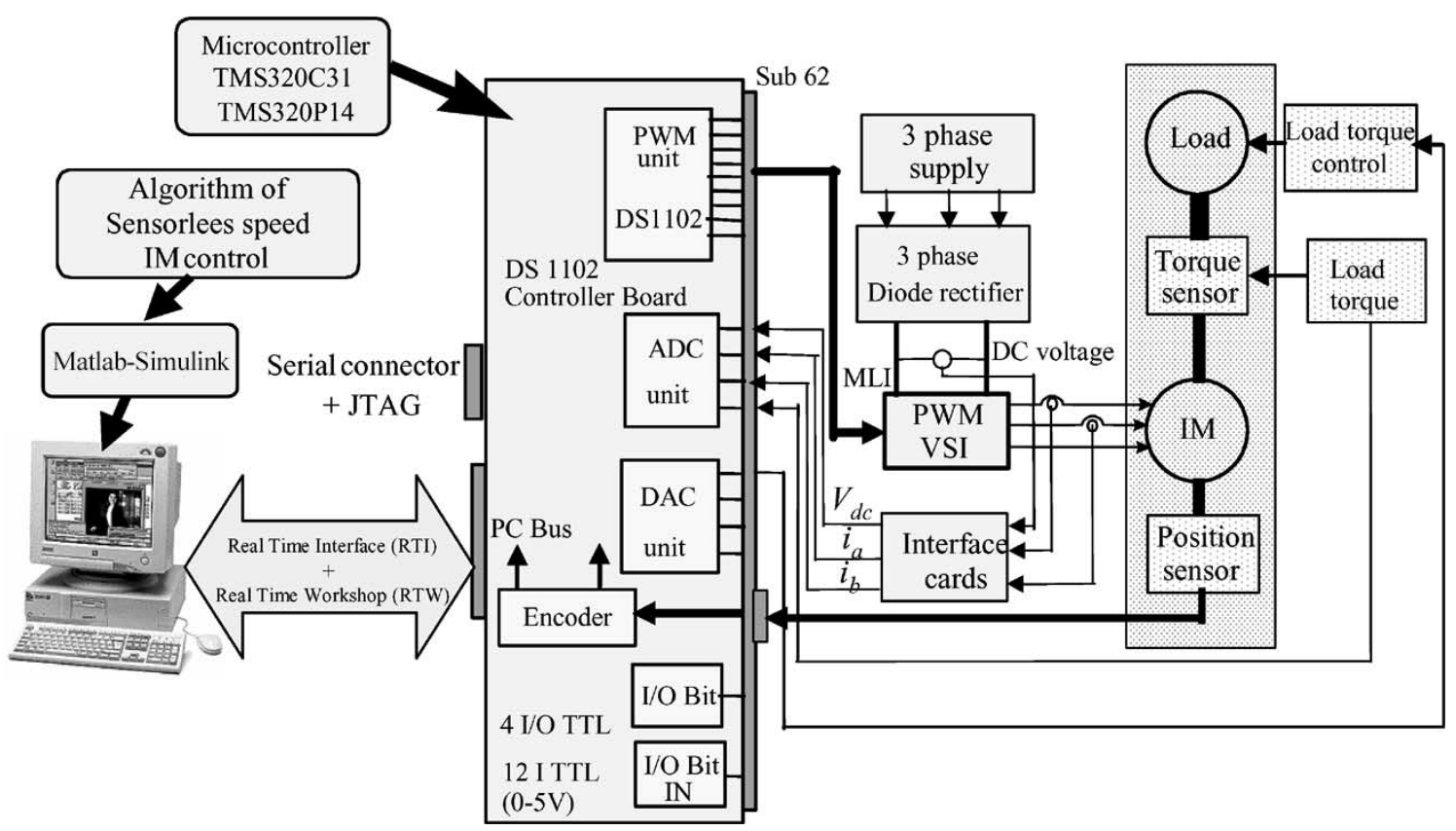

Fig. 7. Experimental drive system configuration.

TABLE I

INDUCTION MOTOR PARAMETERS

\begin{tabular}{ll|ll}
\hline \multicolumn{2}{c|}{ Specification } & \multicolumn{2}{c}{ Parameters } \\
\hline Rated power & $3 \mathrm{~kW}$ & $R_{S}$ & $2.3 \Omega$ \\
\hline Rated voltage & $380 \mathrm{~V}$ & $R_{r}$ & $1.83 \Omega$ \\
\hline Rated Current & $6.6 \mathrm{~A}$ & $L_{S}$ & $0.261 \mathrm{H}$ \\
\hline Rated frequency & $50 \mathrm{~Hz}$ & $L_{r}$ & $0.261 \mathrm{H}$ \\
\hline Number of pole pairs & 2 & $M$ & $0.245 \mathrm{H}$ \\
\hline Rated speed & $1430 \mathrm{r} / \mathrm{min}$ & $J$ & $0.03 \mathrm{Kg} \cdot \mathrm{m}^{2}$ \\
\hline & & $f$ & $0.002 \mathrm{Nm} . \mathrm{rad}^{-1}$ \\
\hline
\end{tabular}

TABLE II

GAINS OF DiFFERENT CONTROLLERS

\begin{tabular}{ll|lc}
\hline$K_{p}$ & 0.5 & $K_{i}$ & 6 \\
\hline$K_{i p}$ & 6.5 & $K_{i i}$ & 673.5 \\
\hline$K_{\omega p}$ & 35.35 & $K_{\omega i}$ & 9780 \\
\hline$k_{r i}$ & 250 & & \\
\hline
\end{tabular}

It is shown [Fig. 8(b)] that the estimated rotor speed has a small steady-state error of about $2 \%$ when the step load torque is applied. This is due to the inaccuracy of the motor parameters, which were calculated from motor rated data.

In Fig. 8(c), it is seen that at steady state the estimated $d, q$ components of the stator flux error appear only during the load torque condition. The error for $d$-axis and $q$-axis stator flux does not exceed $10 \%$ and 5\%, respectively. This difference is due to the fact that the ISFOC method operates in open loop, without any feedback from the stator flux error. In order to avoid such a situation, it is necessary to provide the ISFOC drive system with accurate stator resistance value.

Some experimental results for sensorless speed control are presented here for $1000 \mathrm{r} / \mathrm{min}$ and zero speed reference command. In particular, very satisfactory performances have been obtained for sensorless zero-speed conditions at no-load torque. Both simulation and experimental results of speed, torque, stator flux, and stator current are shown and show close agreement.

For sensorless zero-speed control, it can be noted that the estimated rotor speed, the stator phase current, and the $q$-axis stator current accurately follow its reference. Here, the estimated speed signal coming from the microcontroller is reported, and it can be noted how it accurately tracks the measured speed signal.

Fig. 9 shows zero sensorless speed control when there is an error of $65 \%$ on the stator resistance. As shown in Fig. 9, the sensorless zero-speed control response is not significantly affected by stator resistance variation. To achieve stator resistance variation, we have used in series with each phase of the machine motor a resistance of value $1.5 \Omega$. We start the drive systems without adaptation of the stator resistance and then we use the estimator at $t=3 \mathrm{~s}$ to adjust the stator resistance.

It should be noted that we have considered the rotor resistance to be constant. However, like stator resistance, rotor resistance also depends on temperature. Only the simulation study was carried out in [24] and [25] to investigate the sensitivity of the proposed method on the rotor time constant, which has an influence on the decoupling between the flux and torque and optimal controller. It is clear that an improvement of highperformance sensorless speed control requires tracking changes in rotor resistance.

\section{CONCLUSION}

This paper makes a contribution to the issue of sensorless SFOC of induction motor drive with stator resistance tuning and dynamic feedforward decoupling scheme. A new method has been presented that is able to perform at nominal, low, and 


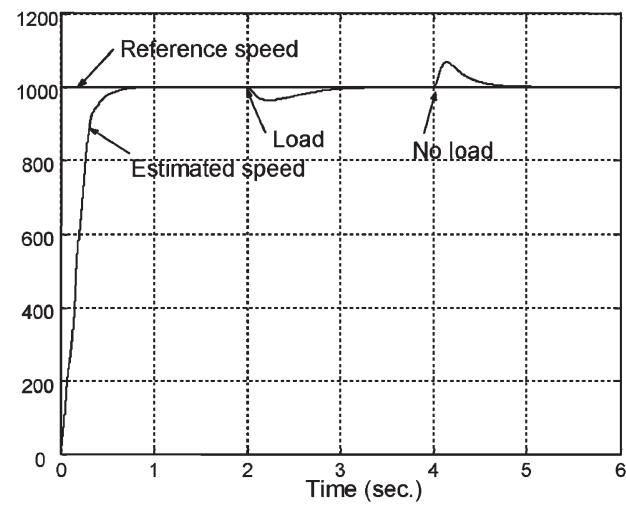

(a)

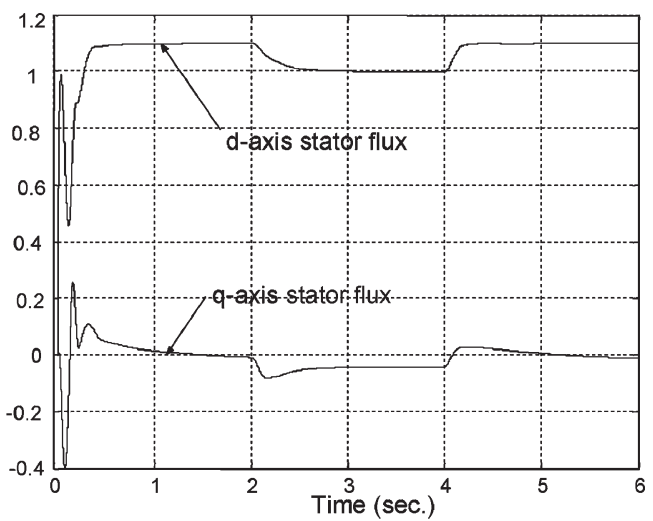

(c)

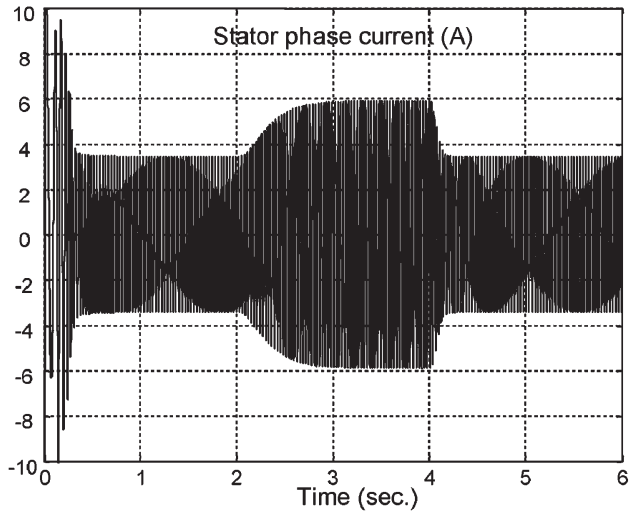

(e)

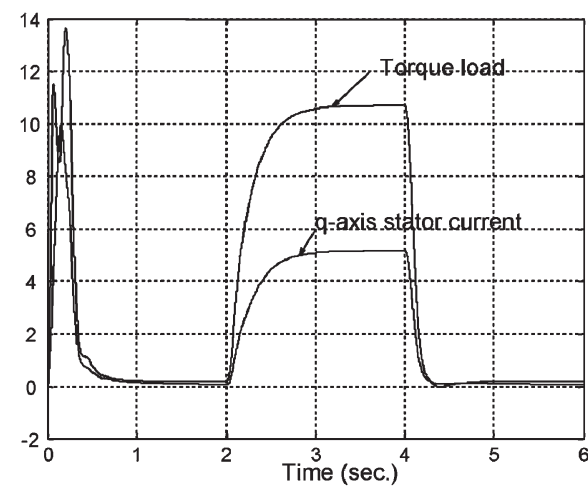

(g)

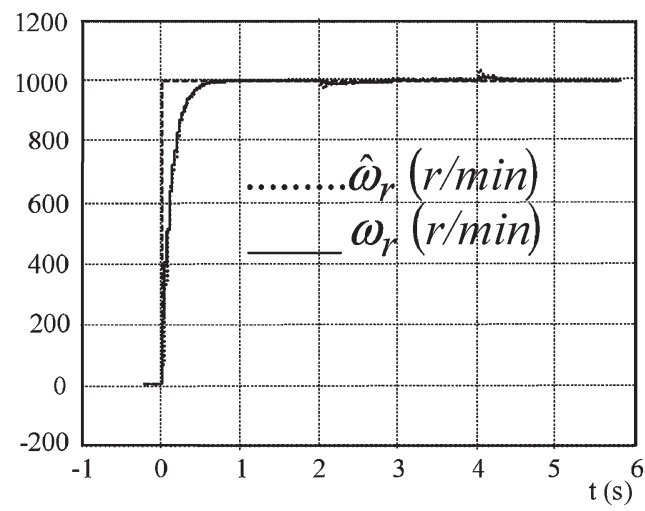

(b)

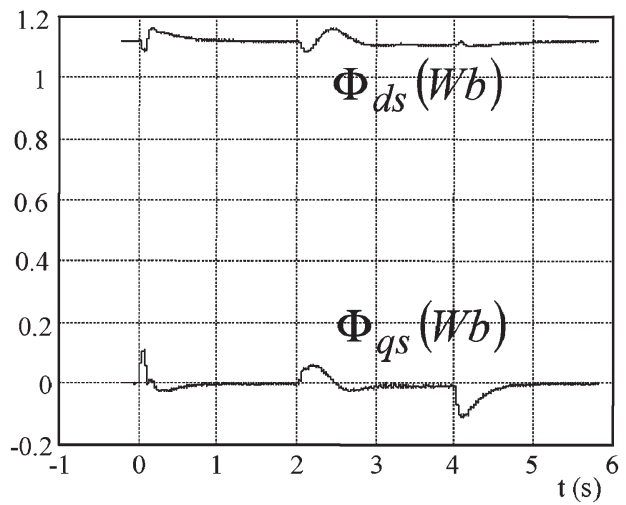

(d)

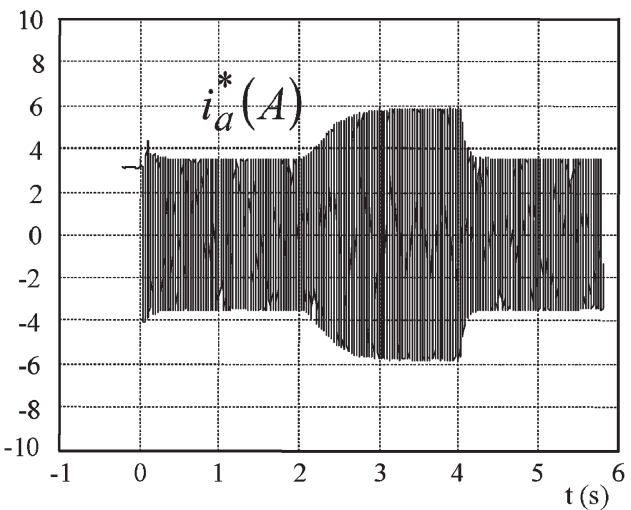

(f)

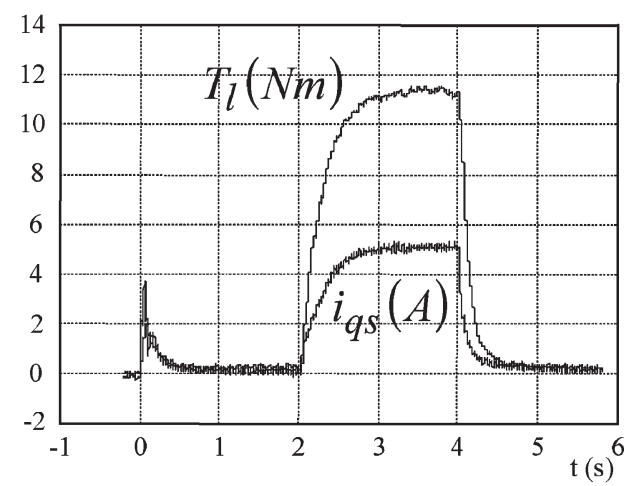

(h)

Fig. 8. Simulation and experimental results of step response $\left(\omega_{r}^{*}=1000 \mathrm{r} / \mathrm{min}\right.$ ) with load torque applied at $2 \mathrm{~s}$. (a) Simulation results of estimated and actual speed responses. (b) Experimental results of estimated and actual speed responses. (c) Simulation results of estimated $d, q$ axis stator flux. (d) Experimental results of estimated $d, q$ axis stator flux. (e) Simulation results of stator phase current. (f) Experimental results of stator phase current. (g) Simulation results of load torque and $q$-axis stator current. (h) Experimental results of load torque and $q$-axis stator current. 


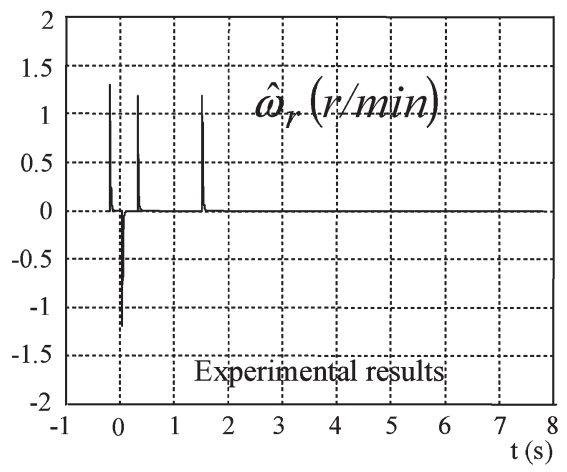

(a)

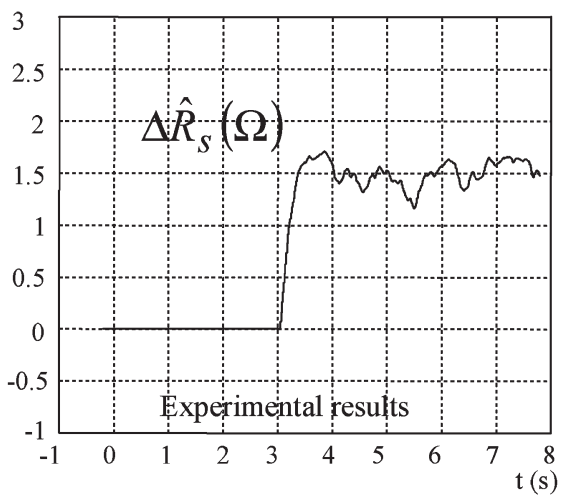

(c)

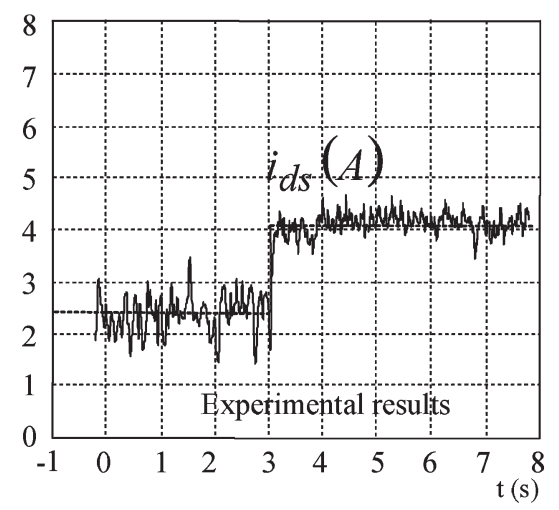

(e)

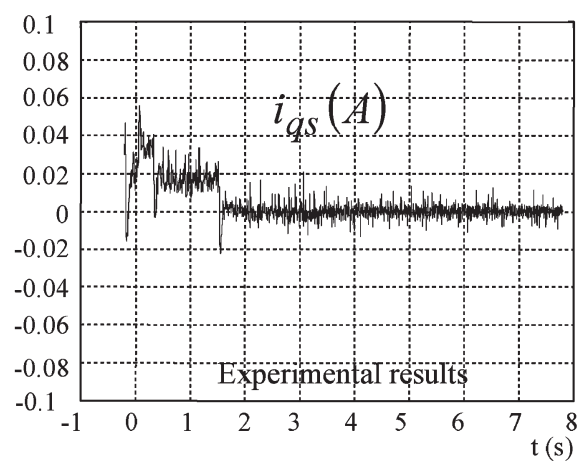

(b)

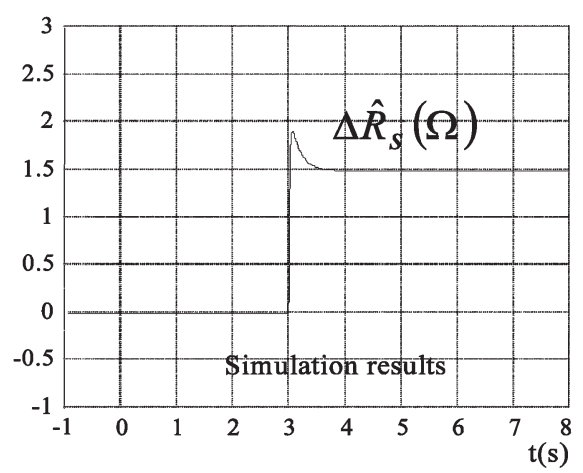

(d)

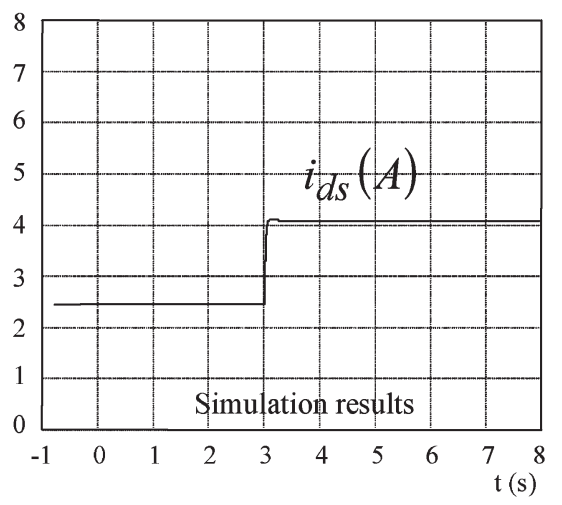

(f)

Fig. 9. Experimental and simulation results of sensorless zero speed command (no load) with stator resistance tuning. (a) Experimental results of zero rotor speed response. (b) Experimental results of $q$-axis stator current. (c) Experimental results of estimated stator resistance variation. (d) Simulation results of estimated stator resistance variation. (e) Experimental results of $d$-axis stator current. (f) Simulation results of $d$-axis current.

zero sensorless speed control of induction motor drive. What is really new, compared to previous works in the literature, is the sensorless control method using slip angular speed estimation with stator resistance tuning based on the error between $d, q$ axis stator currents and that generated by the algorithm command, respectively. Particularly, good performances have been obtained at locked rotor condition, while degradation due to stator resistance variation caused by temperature is taken into account. Simulation and experimental results have shown the practical feasibility of the proposed approach that allows one to estimate both rotor speed and stator resistance variation for a wide speed range. All experimental results confirm the good dynamic performances of the developed drive systems and show the validity of the proposed method.

\section{REFERENCES}

[1] J. Jung and K. Nam, "A dynamic decoupling control scheme for high speed operation of induction motors," IEEE Trans. Ind. Electron., vol. 46, no. 1, pp. 100-110, Feb. 1999.

[2] F. J. Lin, R. J. Wai, C. H. Lin, and D. C. Liu, "Decoupling stator-flux oriented induction motor drive with fuzzy neural network uncertainly observer," IEEE Trans. Ind. Electron., vol. 47, no. 2, pp. 356-367, Apr. 2000.

[3] S. Suwankawin and S. Sangwongwanich, "A speed sensorless IM drive with decoupling control and stability analysis of speed estimation," IEEE Trans. Ind. Electron., vol. 49, no. 2, pp. 444-455, Apr. 2002.

[4] D. Drevensek, D. Zarko, and T. A. Lipo, "A study of sensorless control of induction motor at zero speed utilizing high frequency voltage injection," EPE J., vol. 12, no. 3, pp. 7-11, Aug. 2003.

[5] A. Consoli, G. Scarcella, and A. Testa, "Using the induction motor as flux sensors: New control perspectives for zero-speed operation of standards drives," IEEE Trans. Ind. Electron., vol. 50, no. 5, pp. 1052-1061, Oct. 2003. 
[6] C. Schauder, "Adaptive speed identification for vector control of induction motors without rotational transducers," IEEE Trans. Ind. Appl., vol. 28, no. 5, pp. 1054-1061, Sep./Oct. 1992.

[7] L. Zhen and L. Xu, "Sensorless field orientation control of induction machines based on mutual MRAS scheme," IEEE Trans. Ind. Electron., vol. 45, no. 5, pp. 824-831, Oct. 1998.

[8] Y. R. Kim, S. K. Sul, and M. H. Park, "Speed sensorless vector control of induction motor using an extended Kalman filter," IEEE Trans. Ind. Appl., vol. 30, no. 5, pp. 1225-1233, Sep./Oct. 1994.

[9] K. L. Shi, Y. K. Wong, and S. L. Ho, "Speed estimation of an induction motor drive using an optimized extended Kalman filter," IEEE Trans. Ind. Electron., vol. 49, no. 1, pp. 124-133, Feb. 2002.

[10] S. H. Kim, T. S. Park, and G. T. Park, "Speed sensorless vector control of an induction motor using neural network estimation," IEEE Trans. Power Electron., vol. 48, no. 3, pp. 609-614, Jun. 2001.

[11] L. Ben Brahim, S. Tadakuma, and A. Akdag, "Speed control of induction motor without rotational transducers," IEEE Trans. Ind. Appl., vol. 35, no. 4, pp. 844-850, Jul./Aug. 1999.

[12] H. Kubota, K. Matsuse, and T. Nakano, "DSP-based speed adaptive flux observer of induction motor," IEEE Trans. Ind. Appl., vol. 29, no. 2, pp. 344-348, Mar./Apr. 1993.

[13] G. Yang and T. H. Chin, "Adaptive speed identification scheme for a vector controlled speed sensorless inverter induction motor drive," IEEE Trans. Ind. Appl., vol. 29, no. 4, pp. 820-825, Jul./Aug. 1993.

[14] H. T. Lee, L. C. Fu, and H. S. Huang, "Sensorless speed tracking of induction motor with unknown torque based on maximum power transfer," IEEE Trans. Ind. Electron., vol. 49, no. 4, pp. 911-924, Aug. 2002.

[15] F. Z. Peng and T. Fukao, "Robust speed identification for speed sensorless vector control of induction motors," IEEE Trans. Ind. Appl., vol. 30, no. 5, pp. 1234-1240, Sep./Oct. 1994.

[16] J. Holtz, "Sensorless control of induction motor drives," Proc. IEEE, vol. 90, no. 8, pp. 1359-1394, Aug. 2002.

[17] J. Holtz and J. Quan, "Drift- and parameter compensated flux estimator for persistent zero stator frequency operation of sensorless controlled induction motors," IEEE Trans. Ind. Appl., vol. 39, no. 4, pp. 1052-1060, Jul./Aug. 2003.

[18] T. G. Habetler, F. Perfumo, G. Griva, M. Pastorelli, and A. Bettini, "Stator resistance tuning in a stator flux field oriented drive using an instantaneous hybrid flux estimator," IEEE Trans. Power Electron., vol. 13, no. 1, pp. 125-133, Jan. 1998.

[19] G. Guidi and H. Umida, "A novel stator resistance estimation method for speed-sensorless induction motor drives," IEEE Trans. Ind. Appl., vol. 36, no. 6, pp. 1619-1627, Nov./Dec. 2000.

[20] E. D. Mitronikas, A. N. Safacas, and E. C. Tatakis, "A new stator resistance tuning method for stator flux oriented vector controlled induction motor drive," IEEE Trans. Ind. Electron., vol. 48, no. 6, pp. 1148-1157, Dec. 2001.

[21] J. Kim, K. Nam, J. Chung, and H. Sunwoo, "Sensorless vector control scheme for induction motors based on a stator flux estimator with quadrant error compensation rule," IEEE Trans. Ind. Appl., vol. 39, no. 2, pp. 492-503, Mar./Apr. 2003.

[22] M. H. Shin, D. S. Hyun, S. B. Cho, and S. Y. Choe, "An improved stator flux estimation for speed sensorless stator flux orientation control of induction motors," IEEE Trans. Power Electron., vol. 15, no. 2, pp. 312-318, Mar. 2000.

[23] M. Boussak and K. Jarray, "New stator resistance estimation method for high performance stator-flux oriented sensorless induction motor drives," in Proc. 28th Annu. Meeting IEEE Industrial Electronics Society (IECON), Seville, Spain, Nov. 5-8, 2002, vol. 1, pp. 311-316.
[24] K. Jarray, "Contribution à la commande vectorielle d'un actionneur asynchrone avec et sans capteur mécanique: Conception, réalisation et évaluation de commande numériques par orientation du flux statorique," Ph.D. dissertation, ESM Dept., Université Aix-Marseille III, Marseille, France, Jul. 2000.

[25] M. Boussak, "Synthèse de commandes vectorielles des actionneurs asynchrones et synchrones avec et sans capteur mécanique," Habilitation à Diriger des Recherches (HDR), Université d'Aix Marseille III, Marseille, France, Mar. 30, 2004.

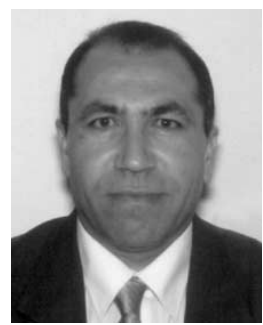

Mohamed Boussak (S'89-M'89) was born in El Haouaria, Tunisia, on December 28, 1958. He received the B.S. and DEA degrees from the Ecole Normale Supérieure de l'Enseignement Technique de Tunis (ENSET), Tunis, Tunisia, in 1983 and 1985 respectively, the $\mathrm{Ph} . \mathrm{D}$. degree from Pierre et Marie Curie University (Paris 6), Paris, France, in 1989, and the "Habilitation à Diriger des Recherches" (HDR) degree from Aix-Marseille III University, Marseille, France, in 2004, all in electrical engineering.

From 1989 to 1990, he was a Researcher at the Ecole Supérieure d'Ingénieurs de Marseille (ESIM), France. From 1990 to 1991, he was a Research Teacher in Electrical Engineering at Claude Bernard of Lyon 1 University, Lyon, France. From 1991 to 2004, he was an Associate Professor at ESIM. Since July 2004, he has been an Associate Professor of Electrical Machines and Drives at the Ecole Généraliste d'Ingénieurs de Marseille (EGIM), France. He has authored more than 60 papers published in international conference proceedings and technical journals in the area as well as many patents. His research is in the areas of electrical machines, power conversion systems, sensorless vector control ac motor drives, advanced digital motion control, and diagnostics.

Dr. Boussak is a member of the IEEE Industry Applications, IEEE Industrial Electronics, and IEEE Power Electronics Societies. He is also a member of the Laboratory of Electrical Engineering Systems (LGSE), Marseille, France. He serves as a member of the Technical Program Committees of several international conferences and technical journals in the power electronics and motor drive fields.

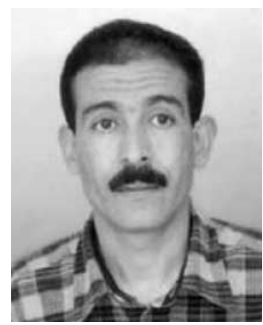

Kamel Jarray was born in Ben Guerdane, Tunisia, on June 18, 1967. He received the B.S. and DEA degrees from the Ecole Supérieure des Sciences et Techniques de Tunis (ESSTT), Tunis, Tunisia, in 1993 and 1995, respectively, and the Ph.D. degree from Aix-Marseille III University, Marseille, France, in 2000, all in electrical engineering.

From 2000 to 2001, he was a Researcher at the Ecole Supérieure d'Ingénieurs de Marseille (ESIM). From 2001 to 2003, he was an Assistant Professor at the Ecole Supérieure des Sciences et Techniques de Tunis (ESSTT), Tunisia. Since September 2003, he has been an Assistant Professor at the Ecole Nationale d'Ingénieurs de Gabès (ENIG), Gabès, Tunisia. His research is in the areas of electrical machines, sensorless vector control ac motor drives, and advanced digital motion control. 